\title{
Semiotics in Academic Training of Culturologists
}

\author{
S. T. Makhlina \\ Department of Theory and History of Culture, St. Petersburg University of Culture and Art, Russia
}

Copyright $(2016$ by authors, all rights reserved. Authors agree that this article remains permanently open access under the terms of the Creative Commons Attribution License 4.0 International License

\begin{abstract}
The article puts under the scrutiny the problem of academic training of semiotics as a part of higher education in Russia. An author provides an overview of the origins of semiotic science, its place within humanities and culture studies, paying a special attention to a historical and modern situation in Russia. An important role of semiotic ideas, notions and terminology not only in academic spheres but in different areas of modern culture and society is analyzed and clearly stated. As a logical conclusion of theoretic and historic overview and analyze of modern-day situation follows an assertion of necessity of semiotic knowledge for students, particularly culturologists. As a practical result, an author provides reasoning and anticipated results as well as logical structure and content of currently-running academic course on Semiotics in the St. Petersburg State Institute of Culture.
\end{abstract}

Keywords Semiotics, Cultural Studies, Culturology, Academic Course on Semiotics, Higher Education in Russia

\section{Place of Semiotics within Modern Humanities}

On the edge of the $19^{\text {th }}$ and $20^{\text {th }}$ centuries a new science, semiotics, emerged. This science about signs was born within linguistics after linguistical approach was introduced to the studies of literature and related areas. Alongside with linguistical approaches a range of mathematical and logical methods were introduced to semiotics. Thus, semiotics emerged as an intersection of several disciplines. The emergence was accidental but its results turned out to be overwhelming. A semiotic perspective put a new slant on a range of research objects like literature, material culture, enabling them to be analyzed from different, previously unknown point of view. Moreover, it was discovered that semiotic methodology is closely related to cybernetics. It was traditionally common to analyze conscious and language as close and interrelated spheres. Language was analyzed solely as an activity, which essence was not identical to its objectified result. But the second half of the $20^{\text {th }}$ century was marked with a start of modernization of traditional rational model of knowledge. It began to be obvious, that genesis and evolution of language lead to social context and language itself became a social factor. It also turned obvious, that socializing function of language can be used to describe a wide range of social practices and ways of interpretation of reality, thus, becoming a practical conscious within social pragmatics. Not by chance, linguistics and semiotics correspondingly, began to be perceived a universal phenomenon of social life, gaining a priority in approaches to solving burning problems of the end of the 20th beginning of the 21 th centuries. That is why all humanities, philosophy among them, find themselves facing a problematics of linguistic meaning as basic within system of scientific education. It was revealed, that language turned to be a social structure, implicated to models of action and interpretation. The development of semiotics in the beginning of the $20^{\text {th }}$ century influenced philosophical theories as well. For instance, Benedetto Croce's book "Aesthetics as a Science of Expression and General Linguistics" (commonly referred to as "Aethetic" in English) [1]. Croce reduced philosophy and aesthetics to symbolic field of linguistics. According to Croce, "expression" a principle of expression, conjoin "general linguistics" and philosophy as being "expressively existential" in their limits. It was Benedetto Croce from whom philosophers of $20^{\text {th }}$ century began their active referrals to the universum of arts and linguistical problems. Subsequently, many philosophers have considered a semiotacal phenomenon of language as a principal method of reality cognition. M. Unamuno predicted "a revitalization of metaphysics in metalinguistics as being true metalogics" [2].

In the end of the $20^{\text {th }}$ century philosophical concepts are getting increasingly aware of symbolical nature of culture as point of research of diverse sphere of artistical and aesthetical experiences, which are subjects to complex study on both theoretical and practical levels. A philosophical research of art in the 20th-21th centuries demands nontraditional cognitional forms and methods as being "congruential to its level of art-existence" [3].

\section{Origins and Need for Semiotic Education in Modern-day Russia}

Here, in Russia, a development of semiotics falls to 
prerevolutionary period and first years after the October revolution. However, an affluence of both art and scientific research approaches in Russia at the time finally turned out to a rivalry between them. In that fight the most substantial, well-grounded and not momentary scientific and artistical approaches were defeated. And these approaches were subject to derision and, later, persecution.

Like this, semiotics alongside with cybernetics, genetics and other advanced scientific approaches, was banned for the first time in Russia. Many of semioticians were persecuted (like M. Bakhtin), their works were forbidden (like O. Freidenbergh's), some of them immigrated (like R. Jacobson).

The Khrushev's Thaw spawned another period of semiotics' prominent development. Many victims of illegitimate oppression were rehabilitated during 1960s, semioticians among them. M. Bakhtin's works were published, playing major part not only in Russian semiotics' development but in Western science as well. Works of O. Freidenbergh and other authors were also published. At that time a famous Moscow-Tartu Semiotics school was founded and began to advance further. Since then not only literature have started to be considered an object of semiotic studies but another forms of art - music, visual arts, films. Moreover, semiotic methods were being applied to other spheres like everyday life and dwelling, ideology, politics. Philosophical studies in semiotics emerged and semiotic methods in psychology and medicine were practiced. Nevertheless, a period of open development of semiotics in Russia was short-term, like Khrushev's Thaw itself, which devolved into The Era of Stagnation (I date the beginning of the Period of Stagnation with 1967). Since that time mass media started a humiliating campaign against semiotic studies, methods and terminology. Many semioticians were forced to emigrate and the only center for semiotic studies remained in Tartu University, in particular the department of Literature, headed by U. Lotman. In response to oppressions a language of studies became increasingly complicated, the term "secondary modeling systems" emerged. A series of "The Summer School for the Study of Secondary Modeling Systems", five in total, were published in Tartu. Publications on semiotics were strongly anticipated both in Russia and other countries, but the spreading of these ideas and the audience was artificially limited. Thus, the development of semiotics in Russia was once again restrained. But despite obstacles, semiotic studies were being held in conjunction with scholars from other cities, primarily Moscow (hence, the "Moscow-Tartu School" name). During the years of the Stagnation Period this center remained the only place for semiotic studies to be conducted. It also worth mentioning that at the beginning of the period of establishment of semiotics, scholars from Saint-Petersburg University played essential part in development of the discipline's major aspects and problems.

The Perestroika brought significant and impressive changes into the society's mentality. Everything previously prohibited rapidly turned allowed to be published. Books and issues on semiotics began to be freely published and widely represented on book market. A new publishing house named "School "Languages of Russian Culture" (Shkola "Yaziki russkoi kulturi" [rus.]) have actively promoted works on semiotics. A sharp rise of interest to semiotic studies has been noticed. Numerous dissertations on semiotics incur no more ostracism. The range of semiotics studies is getting even wider.

And now we are facing a strange situation. On the one hand, the most prominent semioticians like V.V. Ivanov, B.M. Gasparov, A.K. Zolkovsky, M.B. Yampolsky and recently deceased M.L. Gasparov, A.M. Pyatigorsky and others actively publish their works here, in Russian, but reside and generally teach in Western universities. And some of these researchers notice the fading out of semiotics and the necessity of new forces to revitalize it. As a result, the disappointment in and hostility to semiotics, both inner and outer, follows. On the other hand, semiotic studies become fashionable trend.

As specialists are well aware of, the problem of fashion is ambiguous. Initially, it appeals to the most active and enthusiastic ones. A case of Erwin Panofsky, an American art historian (1892-1968), is exemplary enough. He studied law in the Freiburg University in 1910s; wrote his dissertation on Durer's artistic theory in 1915, Berlin. Then Panofsky came to the recently founded University of Hamburg to embrace a position of private-docent, was promoted to a professor rank and finally left University in 1933 with installment of nazi-regime and emigrated to the United States.

Scientific interests of Panofsky were shaped under the influence of classic German philosophy (German idealism), ideas of J. Burckhardt and W. Dilthey. As have been previously mentioned, the rise of interest in linguistics, followed by introduction of semiotics into different areas of study, was characteristic to the turn of the 19-20th centuries. The art history was not exclusion. Specialists in art history were striving to find a language, suitable for expressing modes of representation of artistic images. That's how the science of iconology emerged. Thus, the trend for semiotics spawned a remarkably interesting and scientifically important phenomenon of Erwin Panofsky' works. On its turn, Panofsky's methodology strongly influenced not only historical and art researches but semiotics itself.

To see it from other point, semiotics became a popular and fashionable brand within culture. The fashion trend for semiotics spawned not only numerous scientific works based on semiotic terminology, but wide everyday usage of notions of semiotics. It can be easily understood, as long as culture is a composition on sign systems, with the help of which a unity and uniqueness of human society is kept and guarded. And notions of semiotics are inevitably getting vulgar, losing its initial scientific meaning.

"This is a sign"- can be easily heard nowadays. But what does it really mean? Does every person who use the term "sign" clearly realize the meaning of the word? 
Sign is an object or event which represents another object or event. As an embodiment of mental notions and images, sign enables accumulation, storage and transition of information. Thus, wide-spread saying "this is a sign" turns out to be inaccurate and vulgarized.

On a common basis, notions of "sign" and "symbol" are considered equivalent. But there is an important difference between them.

"Symbol" is a polysemantic notion. In some cases, the notion is wider than the term "sign", in other- narrower than "sign", being one of its forms. Thus, assimilation of the two notion mentioned is unacceptable.

The term "discourse", with the first syllable stressed, is widely used nowadays, while pronunciation is incorrect (the word originates from the French "discours"). The term means coherent text conjoined with pragmatic, sociocultural, psychological factors, etc.; text conceived in eventual context; speech as a purposeful social act and a component of communication and mechanics of cognition processes. Discourse is a speech within context of life itself. That is why "discourse" is not equivalent to "text".

Another fashion of today is a word "simulacrum". It is often clear from the context that usage of this semiotic term is not comprehended by the user. The term "simulacrum" has three meanings in Latin: 1)likeness, similarity 2)image 3)ghost, phantom. This term was appropriated by J.Baudrillard from Epicurus, who understood it as a copy, an image of object. In his turn, Baudrillard used the term to indicate the correspondence between reality and image in postindustrial society. It goes through four consecutive stages: 1) image reflects reality; 2) image transforms and distorts reality; 3 ) image reveals the absence of reality; 4) image lacks connection with reality. The first two stages refer to a Classic period of painting, while the third refers to the period of Industrial epoch with its mass-reproduction of images. Finally, the fours stage refers to a contemporary period described through the term "simulacrum".

Simulacrum is a sign with no denotation; the sign of something not-existing. Simulacrums create an illusion of fullness of existence, the spreading of boundaries of human possibilities; an illusion of intense and consistent life, thus, characterizing the contemporary consumer society. While during previous times, examples of delusive duplicates of objects can be found (like optical illusions dubbed Trompe-l'œil, wide-spread in $18^{\text {th }}$ century), in contemporary culture such simulacrums are omnipresent and ubiquitous.

As often and inaccurate as "simulacrum", a terms "code" and "connotation" are used nowadays.

Code (fr. "code") is a set of particular signs (symbols) and a system of rules with the help of which information can be coded to further transition, processed and stored (captured). Every code is a coherent system of elements of expression which correspondingly code relevant elements of information content.

Connotation is a meaning aspect of sign. It is always build into and can be traced to the relevant denotation.

In some works of contemporary culturologists and art historians and critics not awareness of the basics of semiotic theory is evident.

For instance, a famous art critic mentions "an empty iconic sign". But how is it possible to iconic sign to be empty? Pictorial sign (iconic sign) reproduces in its material contours a structure and contours of denotation.

Examples like this can be easily found further.

Malcolm Bradbury in his picaresque essay "Handbook of a structuralist" ironically describes an affluence of semiotic terminology in contemporary humanities. Bradbury mockingly protests again terms like "methalanguage", "methatext", etc. being widely and inappropriately used far beyond the boundaries of merely philosophy and esthetics. In particular, he states: "at the dawn of the centuries here came Freud with new theories of subconscious, which destroyed the notion of sex as something innocent and, fortunately, an accompanying feeling of guilt. Freud put it clear that everything around us is sex, so that even coughing and riding bicycle became more interesting. The same things are happening now with the field of language. It has lost its innocence. Likewise, semioticians have put it that everything around us is language, with sex in particular. Roland Barthes, the great French semiotician, demonstrated that even food is language; indeed, everything that we put at a display, use as signs to exchange with is language- like sex, food, money, clothes, sports or spouses. Al mentioned are sign systems, controlled by the rate exchange (not bad for a contemporary novel title, indeed). I am language, and you are either, although some of us are good at it and others are not. That's how things are today but don't let it upset you. People didn't give sex down after it lost its innocence. They only lost interest in pretending they are not aware of what they are doing when making sex, which, curiously enough, have existed independently from their speculations. Likewise, the situation is with language. Today we just have to face the fact that all we are a grown-up "signifying", semiotically interacting with each other. Don't panic- you are already included in that system- right now and here. That's why I'd like to say the same things Freud has told to good-old Vienna: "Lay down at the coach and relax. I am here, behind you. And I'm going to help you" [4].

Being a fashion trend, semiotics today undergoes processes of vulgarization and deprivation of meanings. That is a reason why many scholars abandon this science. But like things always are with fashion, decline follows every wide trend and then reappears once again. The same situation the semiotics will face someday, bringing a range of bright aspects and insights of culture and art studies.

\section{An Academic Course on Semiotics in the St. Petersburg State Institute of Culture: Aims, Structure and Content}

The future is generally dependent on the level of higher education, not merely in Russia, but elsewhere in the world. And many people clearly realize it. Not by chance, so many 
novel on higher education problems appeared at the turn of the 20-21th centuries. Among these works are books written by M. Bradbury, the professor of Cambridge University; J. Rota's book; and here, in Russia, examples are, like the recent book by T. Solomatina. All these authors have elaborated on the process of communication between teachers and students, but in fact what they all talking about is a mode of education system operates. Not by chance, the Patriarch Kirill of Moscow puts it unhesitatingly that "education is of the same importance as a problem of state defense and likewise is a national affair. Education system prepares people qualified to work in the contemporary economics of high-technology" [5].

The semiotics of culture and linguistics were logically introduced into the list of the disciplines, compulsory for the student educational program of philosophers and culturologists. And this is clearly reasonable as long as semiotics' influence on the development of contemporary culture is doubtless. Like this, M. Bradbury in his novel "Cuts" depicted novelists strongly influenced by U. Eco, Sh. Endo and mentioned the outstanding role of R. Barthes in shaping the contemporary culture, artistic in particular [6].

According to the position of Russian state legislative organs, semiotics is an essential part of culturology educational background. It should be noticed by teachers that decree of the Government of the Russian Federation claims the following aims should be met in educational process: "1) mastering the content and technologies of education; 2) the development of the system of educational quality improvement; 3 ) improvement of the efficiency of the management system in education sphere; 4) improvement of economical mechanisms in the area of education" [7].

To meet this aims is a difficult task today. The reality is that the general level of education among students is not high enough, which can be traced to the general situation in society. For instance, books are seldom published and get on Russian market without appropriate corrections and, therefore, one can no longer completely rely on books as a way of improving ones educational level. It especially refers to the situation in mass media which is the source of information for general public, youth in particular. Obviously, Internet can be mentioned in this context. Alongside useful and correct information it provides masses of incorrect and harmful.

On the other hand, the informational awareness among youth today sometimes even exceeds the one of their teachers. By the way, the odd and usually inappropriately applied pieces of information on semiotics and linguistics are getting increasingly wide-spread today. Examples abound in mass media.

Undoubtedly, despite all problems and crisises, we can predict that semiotics will progress in its evolution and will face bright scientific breakthroughs. Today semiotic researches are carried out worldwide.

According to the theory coined in the USSR during 1960-1970s, culture is a complex of sign systems with a help of which humanity or a particular nation guards its unity and uniqueness in the process of communication with other cultures and the world. These sign systems, often called "secondary modeling systems" (or "languages of culture") incorporate not only all arts, social activities, and dominant modes of communication in the particular culture (including gestures, clothes, manners, rituals, etc.). Culture also incorporates traditional methods of preserving society's self-identification and historical memory (myths, history, law systems, religion, etc.). Each product of culture should be considered as text produced by one or several sign systems.

Artistic culture is an element of every culture. On its turn, art (or Arts) is a core of artistic culture. And semiotic studies in arts are wide-spread today. The turn of the centuries is marked with the search of new methods and ways of artistic expression. And no research in contemporary artistic culture can be conducted without applying semiotic methods which are getting increasingly wide-used in up-to-date culture studies. This discipline is tough in many institutes of higher education today. It should be mentioned, that the majority of institutes introduce courses based on a programs mastered by the particular teacher of discipline. Thus, some conclusions can be drawn from the analysis of these course programs. As a general rule, teachers of such courses are well-prepared in their sphere of expertise and scientific knowledge. A major part of courses are logically structured and give clear notion of discipline's characteristic and areas of implementation. Each course takes into consideration a specialization of the particular group of students. The process of teaching is easy and complicated at the same time. Complicated- because the profound scientific basis is needed and the general educational level is obviously insufficient. The one going to teach semiotics have to revise and master through a range of scientific works in the relevant field and only this baggage enables a specialist to prepare an interesting course of lectures to introduce students to the actual and widelyapplicable area of scientific knowledge.

A number of anthologies, collections of works on semiotics, are being published today. And many books with inclination into semiotics are being prepared and published.

Nevertheless, the mass of knowledge accumulated during recent years of semiotic studies is so huge, that the matrix is needed to revise and structure the material which appears so actual today. Logically, the discipline is thought in many institutions today. But some requirements to the semiotic educational course should be considered. Obviously, each course on semiotics should start with an insight into the circle of problems of the discipline ant its object. Further, the insight to the history of the particular science should follow. Despite being short chronologically, the history of semiotics, particularly in Russia, is full of prominent works, names and events. A special attention should be paid to the semiotic terminology which is often used inappropriately, with distorted initial meanings.

A semiotics of everyday life is a field of considerable scientific importance. It seems obvious, that everyday life 
with its problems is one of the focuses of contemporary culture studies. That is why this aspect is essential to the course of semiotic studies within system of higher education. But semiotic educational course should also introduce students to research areas beyond problems of merely everyday life. Such aspects as semiotics of scandal, semiotics of war are already included in our course.

Undoubtedly, semiotics of culture should be taught as a special section within educational course. There are a wide range of scientific works for teacher to rely on during the educational process. Semiotics of art might also be structured, in necessary, into complimentary section. The reason is that today the one can hardly do without semiotic terminology trying to comprehend and perceive works of art. As U. Eco states, even iconic sign, the one resembling its particular signifier at its most, is conventionally random and motiveless [8].

The course on semiotics of culture in the St.-Petersburg State University of Culture is structured according to above-mentioned principles. The course is accompanied with a list of texts on semiotics and detailed list of themes for a student essays. But textual tasks can only reflect studied material, so other forms of activity should be embraced to bring out students' creative potential.

As we can witness, the special attention to these actual problems is paid within process of academic training of culturologists.

\section{REFERENCES}

[1] Croce B. Estetika kak nauka o vyrazheni i kak obshchaya lingvistika [rus.]. M., 1920

[2] Bachelard G. Zemlya I grezi voln [rus.]. M., 2000

[3] Kornevishche O. B. Kniga neklassicheskoj estetiki [rus.] M.: IFRAN, 1998. P. 112

[4] Bradbury Malcolm. Tri esse/ Inostrannaya literatura [rus.]. \#12, 2002. P. 242

[5] Voprosy kulturologii [rus.] \#11, 2011. P. 98. [quote from: http:// www. ceninauku. ru/ news/page_27749.htm]

[6] Bradbury Malcolm. Otrazheniya/ Inostrannaya literature [rus.] \#12, 2002. Pp. 175; 180

[7] Postanovlenie pravitelstva RF o Federalnoy celevoy programme razvitiya obrazovaniya na 2006-2010 gg. \#803 ot 23 dekabrya [rus.], 2005

[8] Usmanova A. Umberto Eco: paradoksi interpritacii [rus.] EGY. Propilei, 2000. P. 77 